\title{
Franskan - världsspråk, EU-språk eller bara för fransmän (och några till)
}

\section{Av Eva Larsson Ringqvist, professor i franska}

\author{
Länk till presentation av Eva Larsson Ringqvist
}

\begin{abstract}
Artikelns rubrik är en lätt travestering av titeln på en bok som kom ut för några år sedan och som fick stor uppmärksamhet och mycket lovord. Det var en bok om det engelska språket av Jan Svartvik, tidigare professor i engelska vid Lunds universitet. Boken heter Engelska - öspråk, världsspråk, trendspråk (Norstedts Ordbok, 1999) och den handlar både om engelskans utveckling från de äldsta tiderna och framåt och om engelskans ställning i världen idag.
\end{abstract}

Men denna artikel skall handla om franskan och franskans positioner i världen. Något öspråk har franskan aldrig varit; ett världsspråk är det kanske på sätt och vis fortfarande, men det beror på vad man lägger in i det begreppet. Trendspråk - kanske inte; det fanns en tid då franskan verkligen var ett trendspråk, men den tiden får nog sägas vara förbi. Min hypotes är att när ett språk slutar att vara trendspråk, då är också dess ställning som världsspråk hotad.

Låt oss börja med några motsägelsefulla uppgifter för att problematisera vad som kan tänkas ligga i begreppet världsspråk. I den grammatikbok som ofta används på inledande kurser i franska (Bonniers franska grammatik, 1999) finns det inledningsvis en översikt över det franska språkets utbredning i världen. Det börjar hoppfullt: "On parle français sur les cinq continents" (Franska talas i alla fem världsdelarna) och slutar inte mindre hoppfullt: "Dans le monde, il n’y a jamais eu autant de francophones qu'aujourd'hui!" (Det har aldrig någonsin funnits så många franskspråkiga i världen som idag). Mot detta kan man ställa en mycket mer alarmerande rubrik tagen ur ett slags fransk motsvarighet till Svartviks bok om engelskan, Henriette Walter, Le français dans tous les sens ("franskan på alla håll, på alla ledder", dvs. både ur ett utvecklingsperspektiv och ur ett samtida perspektiv; inom parentes sagt en mycket läsvärd bok även för den som inte har ett specialintresse för fransk språkhistoria). I det kapitel som handlar om franskans ställning utanför själva Frankrike har den första rubriken följande formulering: "Jusqu’où ira la chute?" (Hur stort skall fallet bli?), alltså en rubrik som låter förstå att franskan inte alls är på frammarsch utan att dess roll blir alltmer begränsad i vårt moderna samhälle. Vad ligger bakom de helt olika synsätten i Walters bok och i den franska grammatikboken, kan man undra.

För att få ytterligare en bakgrund till resonemanget om vad som gör ett språk till ett världsspråk kan man betrakta följande tabell från Svartvik (s. 3) om världens största språk. 


\begin{tabular}{|lr|}
\hline \multicolumn{2}{|c|}{ Världens största sprăk } \\
kinesiska & 1071 miljoner \\
engelska & 427 miljoner \\
spanska & 266 miljoner \\
hindi & 182 miljoner \\
arabiska & 181 miljoner \\
portugisiska & 165 milloner \\
bengali & 162 miljoner \\
ryska & 158 miljoner \\
japanska & 124 miljoner \\
tyska & 121 miljoner \\
franska & 116 miljoner \\
\hline
\end{tabular}

Det är en grov uppskattning, ingenting annat är möjligt i många fall, av hur många som talar några olika språk. Franskan hamnar som synes längst ner i denna uppställning, strax under tyskan och japanskan. Man kan lägga märke till att engelskan - världsspråket, trendspråket - inte toppar listan. När man visar en statistik av det här slaget, måste man alltid ta med en hel del förbehåll och förklaringar. Några frågor, som kan verka banala men som inte alls är lätta att svara på, inställer sig genast: "Vad är ett språk?" eller "Vad kan räknas som ett och samma språk?" och "Vem skall räknas in som talare av ett visst språk, bara den som växer upp med språket som modersmål eller också den som lär sig språket senare i livet?" och "Hur väl måste man i så fall behärska språket för att räknas som talare av språket?"

Kinesiskans topposition på listan över världens största språk väcker just den här frågan om vad som egentligen skall räknas som ett enda språk. Inom det som vi kallar för kinesiska finns olika former som vi är vana att kalla för dialekter, men det är inte fråga om dialekter på samma sätt som skånskan och gotländskan är dialekter av det svenska språket. Talare av en kinesisk dialekt har knappast förutsättningar att förstå en talare med en annan kinesisk dialekt men däremot kan de kommunicera skriftligt, därför att det finns ett enhetligt skriftspråk för de olika kinesiska dialekterna. Anledningen till att detta kan fungera är det speciella kinesiska skriftspråket som inte är baserat på att ljudmässigt återge det talade språket utan på bildtecken för olika företeelser. Ett sådant skriftspråk blir mycket stabilt eftersom det inte behöver följa de ljudförändringar som varje språk undergår under århundradenas lopp. Men ur det talade språkets synpunkt vore det kanske riktigare att tala om de olika kinesiska dialekterna som inte bara olika dialekter utan som besläktade men olika språk (ungefär som svenskan och danskan och norskan) och då skulle inte kinesiskans övertag rent statistiskt bli så stort i en tabell som denna.

Svårigheten att ange med någorlunda exakthet hur många som talar ett visst språk, kan illustreras med uppgifter som gäller franskan. Enligt Svartviks tabell rör det sig om 116 miljoner talare. I andra sammanhang, t.ex. i den ovan citerade inledningen till den franska grammatikboken uppges att antalet fransktalande i världen uppgår till omkring 150 miljoner människor. Som man förstår så är det inte någon liten felräkning av befolkningen i något undanskymt utvecklingsland som svarar för den differensen, utan skillnaden beror på hur man räknar, vilka principer man har för att klassa någon som fransktalande.

Så länge som det rör sig om språkligt homogena länder med tillförlitlig befolkningsstatistik är problemet ändå hanterbart. Om man utgår från att det finns ungefär 55 miljoner invånare i Frankrike, kan man anta att det stora flertalet av dessa, men givetvis inte alla, har franska som modersmål, genomgår sin skolutbildning på franska och använder franska i sitt yrkesliv. Men går man bara till de kringliggande länderna Belgien och Schweiz, blir bilden mer komplicerad. Även i dessa länder finns det grupper av befolkningen, betydande grupper, som på samma sätt som befolkningen i Frankrike har franska till modersmål, som utbildningsspråk och som yrkesspråk, men jämsides med dem finns det andra befolkningsgrupper som har flamländska, tyska eller italienska som modersmål. I de senare grupperna, som alltså inte har franskan som modersmål, träffar man ändå på ett betydande antal som behärskar franskan väl på grund av de kontakter över språkgränserna som finns 
inom de respektive länderna, i någon liten mån redan på skolnivån men framför allt genom rörligheten på arbetsmarknaden.

I länder som Belgien och Schweiz kan man leva sitt liv som enbart franskspråkig, en situation som vi återfinner i de franskdominerade delstaterna i Kanada. En väsentlig och nödvändig förutsättning, som är tillgodosedd i dessa länder, är att man som franskspråkig kan få hela sin utbildning, inklusive universitetsutbildning, på franska och att man kan leva i en miljö där franska är kommunikationsmedlet både i det dagliga livet och i kontakter med myndigheter av olika slag.

När dessa förutsättningar inte är uppfyllda, dvs. när man inte har tillgång till skolutbildning på franska och när franskan inte kan användas som kommunikationsmedel i det dagliga livet och i yrkeslivet, kan man befara att franskans ställning som modersmål på sikt är hotad, eftersom de i grunden franskspråkiga i praktiken måste vara tvåspråkiga för att klara sig i samhället. Denna situation präglar de rester av franskspråkighet som t.ex. finns i södra USA i de gamla franska kolonierna, särskilt i delstaten Louisiana. Även om franskan kan leva kvar som ett språk för den privata sfären, lever den farligt. Vilka språk förmedlas vidare till nästa generation i blandäktenskap med en fransktalande men tvåspråkig förälder och en engelsktalande kanske enspråkig förälder? Det brukar vara en bra styrkemätare på de båda konkurrerande språken. En inte särskilt djärv gissning är att det i normalfallet blir enbart engelskan.

Franskspråkigheten i Louisiana liksom i Québec och andra franskspråkiga områden i Kanada är en rest av 1600-talets kolonisationer i västlig riktning. Vad finns kvar som språklig rest av senare kolonisationsvågor, under 1700-talet österut mot Asien och under 1800-talet söderut mot den afrikanska kontinenten? I många av dessa stater lever franskan kvar men sällan som modersmål utan som undervisningsspråk och som statsförvaltningens språk. Liksom engelskan i många av de forna brittiska kolonierna, har franskan, kolonisatörernas språk, fått tjäna som den förenande länken i en i övrigt mycket splittrad språkmiljö. Franskan fick bli det språk som öppnade dörren till högre utbildning i det egna landet eller i Frankrike. Franskan är inte det dagliga umgängesspråket utan ett intellektuellt, akademiskt, kanske också litterärt språk (man kan t.ex. tänka på den senegalesiske poeten Léopold Sédar Senghor). I de tre nordafrikanska staterna Marocko, Tunisien och Algeriet har situationen delvis blivit en annan. Efter frigörelsen har franskan successivt tappat terräng till förmån för arabiskan inom både utbildning och administration. Däremot är kunskaper i franska, åtminstone i en talad vardagsfranska, spridda i stora delar av befolkningen i de mer tättbefolkade områdena. Var och en som rest i de här länderna vet att franskan fortfarande är ytterst gångbar t. ex. i affärer och på hotell och restauranger.

Vilka av alla dessa som här nämnts skall räknas som fransktalande? Naturligtvis alla de som har franska som modersmål, även de som är tvåspråkiga och som kanske inte använder franskan i sitt yrkesliv. Kanske bör man också räkna hit de som fått hela sin utbildning på franska och som använder franskan i sitt yrke. Med en sådan beräkning kommer Henriette Walter, som citerades ovan, fram till ungefärligen följande siffror för fransktalande utanför Frankrike (s 189):

10 millions pour l'Europe (sans la France); 15 millions pour l'Afrique du Nord et le Moyen-Orient; 10 millions pour l'Amérique (Canada, États-Unis, Antilles);

7 millions pour l'Afrique noire;

4 millions pour le reste du monde (océan Indien, Asie, Océanie).

Tillsammans med Frankrikes ca 55 miljoner skulle man komma upp i ca 100 miljoner fransktalande i världen, alltså en något försiktigare siffra än den som angavs i Svartviks tabell.

Vad kan då ligga bakom det optimistiska uttalandet i grammatikboken, "det har aldrig någonsin funnits så många franskspråkiga i världen som idag"? Är det helt taget ur luften? 
Nej, det är det naturligtvis inte, men frågan är om det kan tas till intäkt för att franskans ställning blivit starkare. Det finns två omedelbara orsaker till att antalet fransktalande ökar. Den ena är folkökningen, den andra är att skolgången blivit mer utbredd i t.ex. en del afrikanska länder där franskan tjänar som utbildningsspråk. Men det tycks behövas mer än så för att ett språk skall kunna behålla sin ställning som världsspråk. Svartvik gör, när han talar om de engelsktalande i världen, en indelning i tre kretsar: den inre kretsen som omfattar länder där engelskan är det enda eller i alla fall det dominerande modersmålet (detta skulle för franskans del motsvara Frankrike och delar av Belgien, Schweiz och Kanada), den yttre kretsen omfattar länder där en stor del av befolkningen har engelska som andraspråk ( en situation som närmast motsvarar den som funnits i de nordafrikanska länderna, men där franskan som vi sett tappar mark) och slutligen den växande kretsen, som omfattar länder där engelskan har en stark ställning som främmande språk, alltså som ett språk som många studerar i skolan och lär sig behärska mer eller mindre bra (och här vet vi att franskan är på tillbakagång i många länder, bl.a. i Sverige). Det verkar som om man kommer till en viss brytpunkt, där ett språk blir så dominerande att det blir det självklara valet, om valet finns, för den som skall göra sig ansträngningen att lära ett främmande språk. Franskan kan komma in, liksom tyskan eller spanskan eller ryskan, men först när man uppnår lyxen att få tillfälle att lära sig inte bara ett utan två främmande språk i skolan. Det kan påpekas att EU sedan länge har haft som mål att varje individ skall ha möjlighet att lära sig inte bara ett utan två språk utöver sitt modersmål. Vi har ännu inte uppnått det målet i EU, inte ens i Sverige. Sverige måste ändå bedömas ha ett gott utgångsläge genom att vara ett av de första länderna där ett främmande språk blivit ett obligatoriskt skolämne för alla elever utan att språket har någon annan officiell status i landet.

Man kan spekulera i varför just engelskan tycks ha nått över denna brytpunkt, när det för några sekler sedan säkert vägde betydligt mer jämnt mellan engelskan, franskan, spanskan, portugisiskan och tyskan, som alla spreds över världen med kolonisatörerna. Man kan säkert, med Svartvik, avvisa tanken att det skulle ha något att göra med engelskans inre struktur, att engelskan mer än de andra språken skulle lämpa sig för att läras in av utlänningar. En mycket troligare förklaring har att göra med politisk, kulturell och ekonomisk makt. Utvecklingen av engelskan på den nordamerikanska kontinenten måste ha varit en avgörande faktor. Medan franskan trängdes undan till smärre rester, blev engelskan det dominerande och sammanhållande språket och när USA växte till en stormakt, var det med engelskan som kommunikationsmedel som man utövade och utövar sitt inflytande. Den forna kolonin har tagit över moderlandets roll och blivit den viktigaste garanten för engelskans ställning i världen. För franskan finns ingen liknande utveckling att peka på i de tidigare kolonierna. Om inte USA hade varit, hade förmodligen världens språkliga karta sett mycket annorlunda ut. Den engelske filosofen David Hume förutsåg detta mycket klart redan på 1760-talet när han uttryckte sig ungefär så här: "Låt fransmännen stoltsera med den spridning som deras språk har just nu. Våra fästen i USA är solida och i full tillväxt. De tillförsäkrar det engelska språket en stabilitet och varaktighet som vida överträffar franskans" (citerad av H. Walter, s. 184).

Men USA utövar sitt inflytande inte bara som en politisk stormakt. Engelskan upprätthåller sin ställning som världsspråk genom att också vara ett trendspråk. Vi vet alla hur anglofon och framför allt amerikapåverkad t. ex. massmediavärlden är i ett land som Sverige. Med nya företeelser kommer också de språkliga begreppen, mycket påtagligt inom datorsektorn, IT-branschen, musiksektorn osv. Globaliseringen av näringsliv och vetenskapliga kontakter har vidare framkallat behovet av ett gemensamt kommunikationsmedel och engelskan kommer allt mer självklart att spela den rollen.

I en mycket uppmärksammad lag från 1994 har Frankrike gjort ett försök att bromsa denna utveckling. Syftet med lagen är att säkerställa användningen av franskan i olika offentliga sammanhang. Det kan gälla annonser, varumärkesbeteckningar, avtal och kontrakt, konferenser och publikationer av olika slag. Vid vetenskapliga konferenser t.ex. som anordnas i Frankrike av fransmän, men som mycket väl kan vända sig till en internationell publik, skall varje deltagare ha möjlighet att uttrycka sig på franska i både föredrag och 
debatter. Bötesbeloppen för dem som bryter mot lagen är ganska måttliga, men de finns där stipulerade: $5000 \mathrm{~F}$ för enskild person och $25000 \mathrm{~F}$ för juridisk person. I vad mån en lagstiftning av det här slaget verkligen lyckas stärka ett språks ställning, åtminstone inom landet, är det sannolikt för tidigt att uttala sig om.

När Henriette Walter i sin bok frågar sig hur länge franskans tillbakagång skall fortsätta, jämför hon med en tid då franskan var språket på modet, den tidens trendsspråk, åtminstone i den begränsade del av världen som vi brukar sätta i fokus i historieskrivningen. Franskan talades i s.k. finare kretsar i hela Europa och franska filosofer på modet var gäster vid de kungliga hoven, Voltaire hos Fredrik den II i Preussen och Descartes hos drottning Kristina i Sverige. Rimligen måste man ha kunnat tala med varandra och inte bara om banaliteter. Denna franskans storhetstid har naturligtvis inte gått spårlöst förbi. Här är ett mycket litet axplock av vad som finns kvar i svenskan som lån från franskan:

Heminredning:

Schäslong

Fåtölj

Byrå

Mat:

Champinjon

Dessert

Puré

Militära termer:

Armé

Löjtnant

Diverse småord:

Apropå

Visavi

Pö om pö

Inte minst småorden är viktiga tecken på att ett språk utövar inflytande på ett annat. Att man när man får in en produkt på marknaden också importerar den främmande beteckningen på den produkten är en vanlig företeelse och kanske ett exempel på språklig bekvämlighet, men när ett språk börjar att smitta av sig på andra genom att också exportera diverse småord med en mer abstrakt betydelse, kanske också kraftuttryck, då vet man att det språket verkligen är ett språk på modet, ett trendspråk. Men när hörde man senast någon utbrista Parbleu! - kanske i något teaterstycke från förra sekelskiftet. Nu är det enstaviga engelska kraftuttryck som barn och ungdomar droppar omkring sig i all oskyldighet.

Finns det då ingen nisch kvar där franskan har kvar sin obestridda roll som världsomfattande språk, kan man undra. Länge var den internationella diplomatin ett sådant område. På bilar kunde man och kan man fortfarande se de magiska skyltarna CC och CD som skall uttydas Corps consulaire och Corps diplomatique (konsulskåren och diplomatiska kåren), men officiellt diplomatiskt språk är franskan nu enbart i Vatikanstaten och då delar det den platsen, kuriöst nog, med latinet. Men det finns ett område där franskan, mycket diskret, men ändå tydligt för den som vill se, har en alldeles speciell ställning. Många av oss handskas dagligen med tjänstekuvert men kanske utan att tänka på vad som står i den lilla rutan högst upp till höger, på den plats där frimärket brukar sitta. Där står: Porto betalt - Port payé. Ingen engelska här inte, men vilka relationer postverket har till det franska språket, får utredas i annat sammanhang. Kanske ett ämne för en kommande kandidatuppsats?

(C) Eva Larsson Ringqvist 